\title{
Severe Intrauterine Growth Restriction Is Associated With Higher Spontaneous Carbohydrate Intake in Young Women
}

\author{
MARCO A. BARBIERI, ANDRÉ K. PORTELLA, PATRÍCIA P. SILVEIRA, HELOÍSA BETTIOL, MARILYN AGRANONIK, \\ ANTÔNIO A. SILVA, AND MARCELO Z. GOLDANI
}

\author{
Department of Child Care and Pediatrics [M.A.B., H.B.], Faculty of Medicine of Riberão Preto, São Paulo 14040-904, Brazil; \\ Department of Pediatrics [A.K.P., P.P.S., M.A., M.Z.G.], UFRGS, Rio Grande do Sul 90035-003, Brazil; Department of Public Health \\ [A.A.S.], Federal University of Maranhão, São Luis, Maranhão 65020-070, Brazil
}

\begin{abstract}
Intrauterine growth restriction (IUGR) is associated with metabolic disorders in adulthood. In rats, an early adverse environment alters food preferences in adult life. We investigated whether IUGR is associated with spontaneous macronutrient preferences in humans. Two thousand sixty-three participants from a Brazilian birth cohort were evaluated at 24 y of age using a food frequency questionnaire, physical examination, anthropometric measurements, and biochemical assays (glucose, insulin, cholesterol, and triglycerides). IUGR was defined by the birth weight ratio (BWR = birth weight/mean weight for gestational age). Individuals were classified as non growth restricted (BWR $\geq 0.85$ ), moderately growth restricted $(0.85>\mathrm{BWR} \geq 0.75)$, and severely growth restricted (BWR $<0.75$ ). Severe IUGR women consumed a greater carbohydrate to protein ratio, even after controlling for social variables. There was a continuous association between growth restriction and later carbohydrate to protein ratio consumption in women. Women from both IUGR groups had a larger waist to hip ratio (WHR). The prevalence of metabolic syndrome was comparable between the groups. IUGR women preferred carbohydrates to protein in their regular diet, suggesting that spontaneous food choices may precede the appearance and contribute to the risk for metabolic diseases in this group. (Pediatr Res 65: 215-220, 2009)
\end{abstract}

$\mathrm{S}^{\mathrm{t} u}$ tudies have shown that low birth weight, a marker for adverse fetal conditions, is associated with metabolic disorders in adulthood, predicting insulin resistance and type 2 diabetes (1), hypertension (2), obesity (3) and cardiovascular disease (4), especially in cases where there is evidence of postnatal body weight catch-up during childhood. Thus, feeding patterns and accelerated weight gain during the postnatal period are crucial mediators of the risk for subsequent obesity, cardiovascular disease (5), and insulin resistance (6).

The developing organism may use the maternal intrauterine environment's hormonal milieu as a signal to indicate conditions that will exist in the postnatal environment (7) to favor the adaptation to the environment in which it will develop. Therefore, for a fetus reared in a stressful environment with possible shortage of nutrients, metabolic and neurochemical patterns would be adjusted very early during development favoring energy storage for the individual's survival.

Received February 19, 2008; accepted August 30, 2008.

Correspondence: André Krumel Portella, M.D., M.Sc., Departamento de Pediatria, Ramiro Barcelos, 2350, Largo Eduardo Zaccaro Faraco, 90035-003 Porto Alegre, RS, Brazil; e-mail: andre.portella@ufrgs.br

Supported by Fapesp, Finep, and CNPq.
Studies in animals propose that altered eating and exercise behaviors precede the development of obesity and insulin resistance (8-10). Exposure to a high fat diet further exacerbates the metabolic and cardiovascular abnormalities in these animals (8). In our previous studies in rats $(11,12)$, we demonstrated that early life experience affects sweet food intake later in life. These findings would indicate that adverse perinatal events in humans could affect an individual's voluntary food choices for palatable foods, influencing the risk for metabolic diseases in adult life. We tested this hypothesis in a birth cohort followed to adulthood in Brazil (13).

To our knowledge, this is the first study to assess spontaneous nutritional preferences in adults born with intrauterine growth restriction (IUGR). Thus, the aim of this study is to investigate the possible impact of IUGR on eating preferences and risk factors for metabolic diseases in adult life.

\section{SUBJECTS AND METHODS}

This is a cross-sectional evaluation of a longitudinal, prospective cohort study involving subjects born in Ribeirão Preto (São Paulo, Brazil) from June 1, 1978 to May 31, 1979. There were 9067 births, of which 6973 babies' mothers resided in this city at the time of delivery and were included in the study (6827 singletons and 146 twin deliveries). Data from mothers and children, including anamnesis and anthropometry were collected by trained personnel at the moment of birth. The study was approved by the Ethics Committee of the University Hospital, Medical School of Ribeirão Preto.

The concept of IUGR was based on the birth weight ratio (BWR), the ratio between the newborn's weight and the local population's sex-specific mean birth weight for each gestational age. Individuals were classified as nonrestricted ( $\mathrm{BWR} \geq 0.85$ ), moderately restricted ( $\mathrm{BWR}<0.85$ and $\geq 0.75$ ), and severely growth restricted (BWR $<0.75)$ (14).

In 2004, 2063 participants were reevaluated by anamnesis, physical examination, anthropometric measures, and biochemical assays. The detailed description of the cohort and the comparison of this sample with the original population have been published elsewhere (13). Briefly, the 2004 sample was comparable to the original population with regard to birth weight, birth length, and maternal age, although the sample was slightly wealthier. In this study, only singletons were included. Individuals born before 34 -wk gestation were also excluded (because of the small number of such births, the BWR calculation was not accurate). Therefore, in the present study, we analyzed data from 2050 individuals.

Physical activity was evaluated using the CELAFISCS (15) and centre for disease control (CDC) (16), consensus considering criteria about frequency of activity and dividing individuals into the categories "active" and "sedentary." Maternal data were obtained by a standardized questionnaire soon after delivery, and demographic information was collected from official records (17). The subjects' data were obtained using a standardized questionnaire after their return for evaluation at $24 \mathrm{y}$ of age.

Abbreviation: BWR, birth weight ratio 
The subjects filled in a food frequency questionnaire, developed and adapted for the Brazilian population (18). The usual total caloric intake and the percentages of total calories derived from fat, carbohydrates, and protein were estimated using the DietPRO 4.0 professional program (Agromídia Software). The carbohydrate to protein ratio was calculated by dividing the amount of carbohydrates by the amount of protein consumed.

Weight, height, waist/hip ratio, and blood pressure were measured by trained personnel. Body mass index (BMI) was calculated by dividing weight in kilograms by height in square meters (19). Biochemical measurements included fasting glucose, total cholesterol with fractions and triacylglycerol. Glucose was determined by the GOD/PAP human diagnostic colorimetric enzymatic method (Chronolab AG, Zug, Switzerland). Cholesterol and triacylglycerol were determined by an enzymatic colorimetric method using the Dade Behring XP test and apparatus (Dade Behring, Liederbach, Germany) and reagents from Dade Behring Dimension clinical chemistry.

Metabolic syndrome definition was based on the NCEP ATP III criteria (20), including three or more of the following factors: fasting glucose $\geq 100$ $\mathrm{mg} / \mathrm{dL}$, blood pressure $\geq 130 / 85 \mathrm{~mm} \mathrm{Hg}$, triacylglycerol $\geq 150 \mathrm{mg} / \mathrm{dL}$, HDL cholesterol $>40 \mathrm{mg} / \mathrm{dL}$ for men and $50 \mathrm{mg} / \mathrm{dL}$ for women, and waist circumference $>102 \mathrm{~cm}$ for men and $88 \mathrm{~cm}$ for women.

Statistical analysis. Biochemical measurements and macronutrient intake were evaluated using two-way analysis of variance (ANOVA) with gender and IUGR as factors followed by the Bonferroni post hoc test with interaction evaluation. The model was controlled for maternal (income, smoking, and schooling), and participant factors (smoking, schooling, current BMI, and physical activity). Socioeconomic status (SES) is known to influence food availability and consumption (21), and could impact both the individual's food consumption and the mother's nutrition during pregnancy and lactation. Household education impacts an individual's feeding behavior (22), and there is obvious effects of physical activity and body weight on feeding behavior. Smoking affects feeding related neuropeptides in animals, both when the exposure happens in utero (23) or in adulthood (24). Nicotine affects nutrient intake in humans (25). These variables were therefore identified as possible confounds and the analysis was adjusted accordingly. Anthropometric measurements' analysis had the current BMI excluded from the model. A $\chi^{2}$ test was performed to compare the maternal and subjects data with the prevalence of metabolic syndrome. Linear regression was performed to search for associations between IUGR and later carbohydrate to protein ratio using BWR as a continuous variable. Statistical significance was assumed if the $p$ value was $\leq 5 \%$. Parametric continuous data were expressed as mean $\pm \mathrm{SEM}$.

\section{RESULTS}

Table 1 displays the maternal and subjects' characteristics. One thousand eight hundred thirty nonrestricted, 154 moderately, and 66 severely restricted individuals were included. The overall incidence of IUGR was $10.73 \%$ (7.51\% moderately and $3.22 \%$ severely growth restricted). Evaluation happened at an average age of $23.91 \mathrm{y}(\mathrm{SD}=0.71)$ ranging from 22 to $26 \mathrm{y}$. The prevalence of maternal smoking and low maternal income was greater in the restricted groups $(p<$ 0.001 and $=0.003$ respectively). Subjects' income retained the same pattern of low income in the restricted groups $(p=$ 0.01 ), but the prevalence of smoking was not different between the groups $(p=0.293)$.

$\chi^{2}$ analysis indicated that women are more sedentary than men $(p<0.01)$. However, the prevalence of sedentarism was not different between the IUGR groups in women (Severe IUGR $=32.4 \%$; Moderate IUGR $=29.4 \%$; No IUGR $=$ $26.8 \%, p=0.30$ ) or in men (Severe IUGR $=27.6 \%$; Moderate IUGR $=13 \%$; No IUGR $=14.5 \%, p=0.18$ ).

The consumption of macronutrients is shown in Figure 1. The total caloric consumption was not different between the groups $(p=0.429)$, although men consumed more calories than women $(p<0.001)$, without interactions $(p=0.220)$. Fat consumption was similar between the groups $(p=0.561)$ and genders $(p=0.280)$; however, an effect of sex and an
Table 1. Socioeconomic characteristics distribution of the subjects by birth weight ratio category

\begin{tabular}{|c|c|c|c|c|}
\hline & $\begin{array}{l}\text { Severely } \\
\text { restricted } \\
(n=66)\end{array}$ & $\begin{array}{l}\text { Moderately } \\
\text { restricted } \\
(n=154)\end{array}$ & $\begin{array}{l}\text { No growth } \\
\text { restriction } \\
(n=1830)\end{array}$ & $p$ value \\
\hline \multicolumn{5}{|l|}{ Maternal factors, n (\%) } \\
\hline Smoking (ever) & & & & $<0.001$ \\
\hline No & $33(50.80)$ & $99(64.70)$ & $1369(76.40)$ & \\
\hline Yes & $32(49.20)$ & $54(35.30)$ & $423(23.60)$ & \\
\hline $\begin{array}{l}\text { Family income } \\
\text { (minimum } \\
\text { wages), n (\%) }\end{array}$ & & & & 0.003 \\
\hline$<3 \mathrm{MW}$ & $12(18.18)$ & $24(15.58)$ & $182(9.95)$ & \\
\hline 3 a $4,9 \mathrm{MW}$ & $17(25.76)$ & $36(23.38)$ & $404(22.08)$ & \\
\hline 5 a $9,9 \mathrm{MW}$ & $18(27.27)$ & $49(31.82)$ & $560(30.60)$ & \\
\hline 10 a $19,9 \mathrm{MW}$ & $7(10.61)$ & $16(10.39)$ & $379(20.71)$ & \\
\hline$\geq 20 \mathrm{MW}$ & $2(3.03)$ & $17(11.04)$ & $177(9.67)$ & \\
\hline Schooling, n (\%) & & & & 0.125 \\
\hline$<5$ years & $40(62.50)$ & 75 (49.02) & $798(44.51)$ & \\
\hline 5 to 8 years & $14(21.88)$ & $41(26.80)$ & $497(27.72)$ & \\
\hline 9 to 11 years & $7(10.94)$ & $21(13.73)$ & $303(16.90)$ & \\
\hline$\geq 12$ years & $3(4.69)$ & $16(10.46)$ & $195(10.88)$ & \\
\hline \multicolumn{5}{|l|}{ Subject's factors } \\
\hline Sex, n $(\%)$ & & & & 0.533 \\
\hline Male & $29(43.90)$ & $69(44.80)$ & $888(48.50)$ & \\
\hline Female & $37(56.10)$ & $85(55.20)$ & $942(51.50)$ & \\
\hline Smoking, n (\%) & & & & 0.292 \\
\hline Never smoked & $47(71.21)$ & $116(75.32)$ & $1381(75.46)$ & \\
\hline Ex-smoker & $4(6.06)$ & $12(7.79)$ & $137(7.49)$ & \\
\hline$<5$ cigarettes/day & $2(3.03)$ & $7(4.55)$ & $118(6.45)$ & \\
\hline$\geq 5$ cigarettes/day & $13(19.70)$ & $19(12.34)$ & $194(10.60)$ & \\
\hline Schooling, n (\%) & & & & $<0.001$ \\
\hline$<8$ years & $21(31.82)$ & $27(17.53)$ & $268(14.64)$ & \\
\hline 9 to 11 years & $33(50.00)$ & $86(55.84)$ & $914(49.95)$ & \\
\hline$\geq 12$ years & $12(18.18)$ & $41(26.62)$ & $648(35.41)$ & \\
\hline
\end{tabular}

Chi-square analysis performed comparing birth weight groups. Totals may differ for some variables because of missing data.

interaction between gender and group was found for carbohydrate consumption, in which women ate more carbohydrates than men $(p=0.049)$, and severely growth restricted women ate more carbohydrates than the non growth restricted women $(p=0.041$ for sex-group interaction; Severe IUGR women $=$ $50.995 \%$, IC95\% $=48.458-53.533 \%$; Moderate IUGR women $=47.624 \%$, IC95\% $=46.083-49.166 \%$; Non-IUGR women $=47.095$, IC95\% $=46.632-47.559 \%)$. This was accompanied by a decreased ingestion of protein in the same group $(p=0.014$ for the interaction; Severe IUGR women $=$ $13.965 \%$, IC95\% $=12.843-15.088 \%$; Moderate IUGR women $=15.901 \%$, IC95\% $=15.219-16.583 \% ;$ Non-IUGR women $=15.897$, IC95\% $=15.692-16.102 \%)$. These findings led to a higher carbohydrate to protein ratio in the severely growth restricted group $(p=0.033$ for sex and $p=$ 0.010 for the interaction; Severe IUGR women $=3.844$, IC95\% $=3.450-4.238$; Moderate IUGR women $=3.189$, IC95\% $=2.950-3.428 ;$ Non-IUGR women $=3.137$, IC95\% $=$ 3.066 to 3.209). The same results are found if the analysis is adjusted for current body weight instead of current BMI (data not shown). Regression analysis showed a continuous association between growth restriction and later carbohydrate to protein ratio consumption in women $(\beta=-0.825$, IC-95\%: -1.320 to -0.323$)$. 

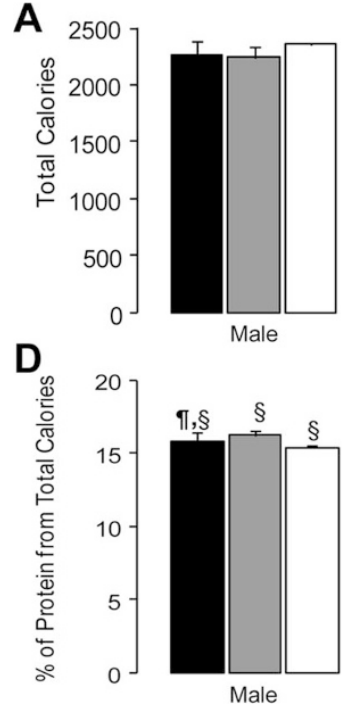
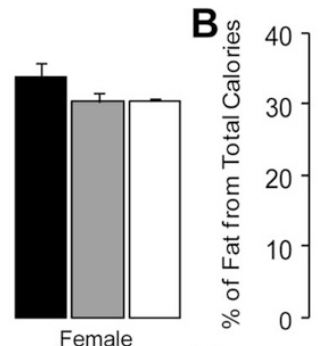

E
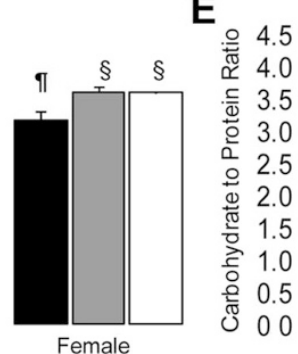

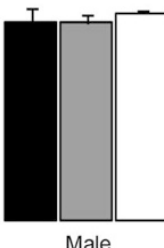

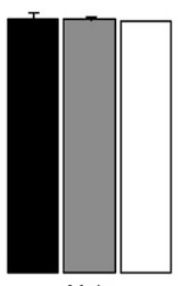
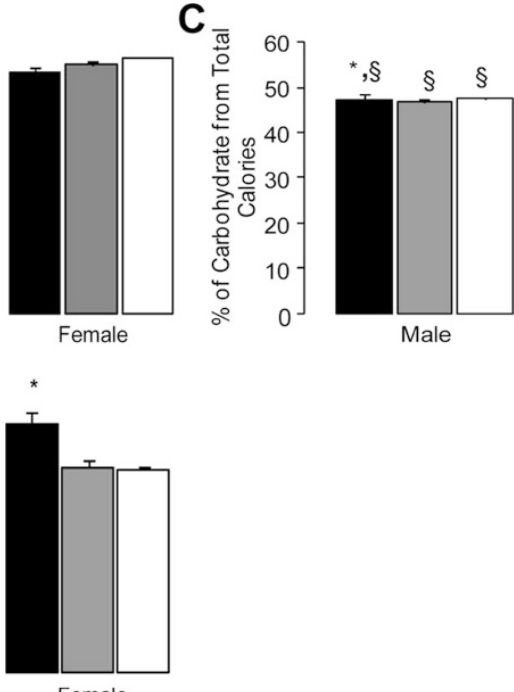

Female

Figure 1. Nonadjusted mean and SEM of macronutrient consumption in severely restricted (Severe IUGR, black bar), moderately restricted (Moderate IUGR, gray bar), and nonrestricted (No IUGR, white bar) individuals. A: Total caloric intake. B: Percentage of the total calories derived from fat. $C$ : Percentage of the total calories derived from carbohydrates. $D$ : Percentage of the total calories derived from protein. $E$ : carbohydrate to protein ratio. *Two-way ANOVA adjusted for maternal (income, smoking, and schooling) and participant factors (smoking, schooling, current BMI and physical activity) followed by interaction evaluation (sex versus group), $p<0.05$. Different symbols on top of the bars demonstrate differences between the groups after the interaction evaluation.

Table 2. Consumption of specific types of foods

\begin{tabular}{|c|c|c|c|c|c|c|}
\hline & \multicolumn{3}{|c|}{ Men } & \multicolumn{3}{|c|}{ Women } \\
\hline & $\begin{array}{l}\text { Severe IUGR } \\
\quad(n=29)\end{array}$ & $\begin{array}{l}\text { Mild IUGR } \\
\quad(n=69)\end{array}$ & $\begin{array}{l}\text { No IUGR } \\
(n=888)\end{array}$ & $\begin{array}{l}\text { Severe IUGR } \\
\quad(n=37)\end{array}$ & $\begin{array}{l}\text { Mild IUGR } \\
(n=85)\end{array}$ & $\begin{array}{l}\text { No IUGR } \\
(n=942)\end{array}$ \\
\hline \multicolumn{7}{|l|}{ Food } \\
\hline Meat* & $1.91 \pm 0.17$ & $2.12 \pm 0.11$ & $2.06 \pm 0.03$ & $1.65 \pm 0.17$ & $1.67 \pm 0.10$ & $1.78 \pm 0.03$ \\
\hline Milk & $1.67 \pm 0.24$ & $1.60 \pm 0.15$ & $1.68 \pm 0.04$ & $1.48 \pm 0.23$ & $1.71 \pm 0.14$ & $1.75 \pm 0.04$ \\
\hline Bread & $3.51 \pm 0.28$ & $3.57 \pm 0.18$ & $3.80 \pm 0.05$ & $3.91 \pm 0.27$ & $3.59 \pm 0.16$ & $3.58 \pm 0.05$ \\
\hline Fruits & $1.24 \pm 0.20$ & $1.19 \pm 0.13$ & $1.21 \pm 0.04$ & $1.52 \pm 0.19$ & $1.29 \pm 0.11$ & $1.26 \pm 0.03$ \\
\hline Vegetables* & $1.97 \pm 0.44$ & $2.95 \pm 0.28$ & $2.78 \pm 0.08$ & $3.75 \pm 0.42$ & $3.21 \pm 0.26$ & $3.21 \pm 0.08$ \\
\hline $\begin{array}{l}\text { Calories derived from } \\
\text { sweet foods }\end{array}$ & $275.30 \pm 42.16$ & $268.26 \pm 27.04$ & $293.00 \pm 7.61$ & $297.52 \pm 40.61$ & $219.24 \pm 24.67$ & $237.79 \pm 7.45$ \\
\hline Fiber $(\mathrm{g})^{*}$ & $16.85 \pm 1.34$ & $16.47 \pm 0.86$ & $16.79 \pm 0.24$ & $16.03 \pm 1.29$ & $14.40 \pm 0.78$ & $14.13 \pm 0.24$ \\
\hline
\end{tabular}

For continuum data two way analysis of variance (ANOVA) (Sex vs. BWR-Group) was used. The test was followed by Bonferroni post hoc or interaction evaluation. Data expressed by mean \pm standard error of mean. For categorical data, we used $\chi^{2}$ test. Data expressed in $n(\%)$. Totals may differ for some variables because of missing data.

* Effect of sex. Meat, milk, bread, fruits and vegetables—number of portions per day.

IUGR, intrauterine growth restriction.

Table 2 depicts the consumption of specific types of foods. There were no differences between the groups regarding the consumption of milk, meat, bread, vegetables, fruits, and fiber $(p>0.05)$, nor in the mean total calories derived from sweet food.

Table 3 displays the anthropometric and biochemical data. IUGR individuals were smaller $(p<0.001)$ and lighter $(p=$ 0.005 ) than nongrowth restricted individuals, but the BMI was only lower in the moderately growth restricted group in comparison with the nongrowth restricted group $(p=0.035)$. The waist to hip ratio (WHR) was larger in IUGR women $(p=0.017$ for sex-group interaction; Severe IUGR women $=$ 0.782 , IC95\% $=0.762-0.801 ;$ Moderate IUGR women $=$ 0.773 , IC95\% $=0.762-0.785 ;$ Non-IUGR women $=0.757$, $\mathrm{IC} 95 \%=7.53-7.60)$.

The prevalence of risk factors for metabolic syndrome, such as plasma fasting glucose, HDL and triacylglycerol did not differ between the groups (Table 3), although there were gender effects as expected (data not shown).

\section{DISCUSSION}

Our results demonstrate a higher ingestion of carbohydrates in women born with severe IUGR. This was accompanied by a diminished consumption of protein, leading to a higher carbohydrate to protein ratio. To our knowledge, this is the first evidence indicating an association between IUGR and altered feeding preferences in humans. The effect persisted when confounders such as SES, current BMI, and smoking were considered. Furthermore, a continuous association was found between IUGR and the preference for carbohydrates in adulthood.

IUGR may be considered a metabolic stress that acts during a susceptible period, programming the hypothalamic circuitry 
Table 3. Anthropometry and prevalence of metabolic syndrome by birth weight ratio category and sex

\begin{tabular}{|c|c|c|c|c|c|c|}
\hline & \multicolumn{3}{|c|}{ Men } & \multicolumn{3}{|c|}{ Women } \\
\hline & $\begin{array}{l}\text { Severe IUGR } \\
\quad(n=29)\end{array}$ & $\begin{array}{l}\text { Moderate IUGR } \\
\quad(n=69)\end{array}$ & $\begin{array}{l}\text { No IUGR } \\
(n=888)\end{array}$ & $\begin{array}{l}\text { Severe IUGR } \\
\quad(n=37)\end{array}$ & $\begin{array}{l}\text { Moderate IUGR } \\
\quad(n=85)\end{array}$ & $\begin{array}{l}\text { No IUGR } \\
(n=942)\end{array}$ \\
\hline \multicolumn{7}{|c|}{ Anthropometric data, mean (SEM) } \\
\hline Length $(\mathrm{cm})^{*}, \dagger$ & $172.76(0.90)$ & $172.54(0.80)$ & $176.32(0.22)$ & $159.1(1.20)$ & $159.88(0.66)$ & $162.96(0.21)$ \\
\hline Weight $(\mathrm{Kg})^{*}, \dagger$ & $73.81(2.95)$ & $73.07(1.75)$ & $78.02(0.50)$ & $59.50(2.55)$ & $58.12(1.50)$ & $63.10(0.46)$ \\
\hline BMI $\left(\mathrm{Kg} / \mathrm{m}^{2}\right)^{*}$ & $24.67(0.85)$ & $24.4(0.49)$ & $25.04(0.15)$ & $23.35(0.87)$ & $22.84(0.57)$ & $23.71(0.16)$ \\
\hline WHR & $0.86(0.011)$ & $0.85(0.007)$ & $0.86(0.002)$ & $0.78(0.010) \S$ & $0.77(0.007) \S$ & $0.76(0.002)$ \\
\hline \multicolumn{7}{|c|}{ Prevalence of metabolic syndrome, number of cases ( $\%$ of total) } \\
\hline NCEP ATP III & $4(13.79 \%)$ & $6(8.69 \%)$ & $110(12.38 \%)$ & $1(2.70 \%)$ & $3(3.53 \%)$ & $52(5.52 \%)$ \\
\hline Unknown & $1(3.44 \%)$ & $1(1.45 \%)$ & $6(0.67 \%)$ & $1(2.70 \%)$ & 0 & $21(2.23 \%)$ \\
\hline$\chi^{2}$ value & & & 0.712 & & & 0.554 \\
\hline
\end{tabular}

For continuum data two way ANOVA (Sex vs. BWR-Group) was used. The test was followed by Bonferroni post hoc or interaction evaluation. For categorical data we used $\chi^{2}$ test. Data expressed in $n(\%)$. Totals may differ for some variables because of missing data. Statistical significance was assumed if $p$ value was less than 0.05 .

* Effect of sex.

$\dagger$ Effect of BWR-Group.

† Sex vs. BWR-group interaction.

$\S$ Analysis of interaction, groups which CI95\% differ from No IUGR group.

SEM, standard error of mean; IUGR, intrauterine growth restriction; BMI, body mass index; WHR, waist to hip ratio; NCEP-ATP III, national cholesterol education program, adult treatment panel III criteria for diagnosing metabolic syndrome.

responsible for appetite regulation, and/or the mesolimbic pathways responsible for the pleasure associated with the ingestion of highly palatable, preferred foods. The programming of the hypothalamic-pituitary-adrenal (HPA) axis has been proposed as a possible mechanism by which IUGR leads to increased risk for metabolic diseases in adulthood (26), and could also be involved in the establishment of feeding preferences. IUGR children have an exacerbated adrenocortical response to stress (27), and glucocorticoids stimulate behaviors mediated by the "reward" pathways, increasing palatable feeding in rats $(28,29)$ and humans $(30)$. The ingestion of preferred foods in the context of elevated glucocorticoids and insulin leads to an increased accumulation of abdominal fat (29). Interestingly, the waist/hip ratio was larger in IUGR women in our sample. This agrees with findings from the Dutch Famine in which BMI is increased in women exposed to undernutrition in early gestation (31). There is also a greater transfer of glucocorticoids across the placenta of female when compared with male fetuses (32), supporting the fact that differences in feeding were only associated with IUGR in women.

Although developmental programming is adaptive, in a situation where a mismatch between the early prenatal and the postnatal environments occurs, maladaptive consequences such as obesity may become prevalent (7). Intriguingly, neonatal leptin treatment reverses such programming in rats (33). The programming of leptin secretion, a hormone involved in the signaling of energy stores to central regulators, is a possible mechanism by which early life insults lead to increased risk for metabolic diseases in adulthood. Because this hormone is also related to appetite regulation and taste perception (34), altered leptin secretion could be involved in the establishment of feeding preferences in subjects who have suffered IUGR, leading to obesity and metabolic syndrome in later life.

The analysis of specific foods reveals that the effect of severe IUGR in increasing carbohydrate and decreasing pro- tein consumption is distributed across different types of foods and is not because of the over or under consumption of any one food. This is important, because one could expect less meat and more bread intake in poorer families where IUGR would be more prevalent. Therefore, our findings are probably not related to SES but to a genuine preference in this group. The mean caloric intake from sweet foods was similar, but it is important to note that these foods are a mixture of different types of carbohydrates, protein, and fat. As with any dietary assessment tool, there are limitations to the use of our food frequency questionnaire. No questionnaire will retrieve unique aspects of dietary data unless it is designed to specifically assess them, and in this study, the focus was to classify individuals according to their preferred macronutrient class.

Shultis et al. (35) described associations between birth weight and the consumption of macronutrients in childhood that did not persist after gestational age and social variables were accounted for, except a negative association between birth weight and saturated fat intake at 43 mo of age. At this age, food intake is still very much influenced by parental behavior (36), and parents of low-birth weight children feed their babies differently to encourage them to grow larger (37). The same study did not find effects of low birth weight on feeding preferences at $7 \mathrm{y}$ of age. In our study, we show that IUGR is associated with spontaneous macronutrient choices in adulthood, leading to increased carbohydrate and decreased protein consumption. It is possible that these preferences establish only after puberty, needing a specific hormonal milieu and/or fat distribution to be expressed. This hypothesis deserves further investigation, but is in accordance to our findings in rats (38).

The prevalence of metabolic syndrome was not different between the groups in this study. However, our sample is young and does not exclude the possibility that food choices in the growth restricted group would finally lead to an altered biochemical profile after a longer period of time. It may be that the differences in food preferences precede the establish- 
ment of metabolic syndrome, predisposing the IUGR individuals to be more likely to develop metabolic syndrome. Although the prevalence of metabolic syndrome may appear high for the age group, studies conducted on different populations reveal a high prevalence of metabolic syndrome depending on the criterion used, with rates ranging from $12.4 \%$ to $28.5 \%$ among men and from $10.7 \%$ to $40.5 \%$ among women (39). A recent Brazilian study using national survey statistics (40) demonstrates a prevalence and gender distribution of overweight and obesity similar to our sample.

Recent data indicate that higher dietary glycemic load, because of replacing fats with carbohydrates or increasing the intake of rapidly absorbed sugars, predicts greater coronary heart disease risk (41). Physiologic hyperglycemia induces overproduction of superoxide by the mitochondrial electrontransport chain, resulting in inflammatory responses and endothelial dysfunction (42). Studies in overweight women have shown that diets with a decreased carbohydrate to protein ratio have positive effects on body composition, blood lipids, and glucose homeostasis $(43,44)$. Therefore, the spontaneous preference for carbohydrates instead of protein, especially in the population of IUGR individuals, may play a role in the increased risk for metabolic disease largely reported in this group.

Our main finding was evident only in women. Importantly, women are more prone to eating disturbances; therefore, it is possible that the preference is clearer and/or appears earlier in women than in men. Although the effect size may appear small, when considering lifestyle variation and food consumption, even small but chronic increases in the intake of specific macronutrients could impact health. For instance, a higher spontaneous carbohydrate intake is associated with an increased risk for hemorrhagic stroke in women (45). Other studies have found that women are less physically active than men, as reported in our sample (46-48). Because our assessment is based in an overall estimation (including activity during work hours), this was expected because men are more likely to be enrolled in jobs requiring physical strength.

Some other limitations should be taken into consideration. The small number of IUGR individuals could underestimate the effect of IUGR on food consumption, particularly in men. Lack of precision in food questionnaires could lead to an underestimation of the proportion of protein in the diet and an overestimation of carbohydrate intake (49). However, in this case, the entire sample would be subjected to this same limitation. The food frequency questionnaire is based on usual dietary patterns and could reflect availability and convenience rather than actual preferences. In addition, the low SES associated with IUGR could play a role in feeding habits, because foods rich in carbohydrates are usually less expensive than protein. Our results though persisted even after controlling for such variables. Moreover, recent research shows that evaluations of habitual consumption using food frequency questionnaires correlate well with the actual preference for certain foods (50).

We did not collect data on breastfeeding during the neonatal period. Reliability of breastfeeding retrospectively collected data, especially in long-term follow-up studies is debatable
$(51,52)$. Although some studies report a protective effect of breastfeeding against obesity in childhood (53), it is not known if these findings persist to later ages $(54,55)$. The same is true for the influence of breastfeeding in food neophobia (56), reported in children but remaining to be investigated in adulthood. Therefore, we think that, if any, the impact of this variable in our findings is subtle.

In conclusion, we propose that an alteration in feeding preferences such as the increased preference for carbohydrate consumption associated with severe IUGR in women may further increase the risk for cardiovascular and metabolic diseases among these individuals. The quality of the fetal environment is thus associated with specific eating preferences in adulthood, and a chronic consumption of hyper palatable foods could contribute to the development of obesity and related disorders in IUGR individuals.

\section{REFERENCES}

1. Forsen T, Eriksson J, Tuomilehto J, Reunanen A, Osmond C, Barker D 2000 The fetal and childhood growth of persons who develop type 2 diabetes. Ann Intern Med 133:176-182

2. Law CM, Shiell AW, Newsome CA, Syddall HE, Shinebourne EA, Fayers PM, Martyn CN, de Swiet M 2002 Fetal, infant, and childhood growth and adult blood pressure: a longitudinal study from birth to 22 years of age. Circulation 105:10881092

3. Laitinen J, Pietilainen K, Wadsworth M, Sovio U, Jarvelin MR 2004 Predictors of abdominal obesity among 31-y-old men and women born in Northern Finland in 1966. Eur J Clin Nutr 58:180-190

4. Barker DJ, Osmond C, Forsen TJ, Kajantie E, Eriksson JG 2005 Trajectories of growth among children who have coronary events as adults. N Engl J Med 353:1802-1809

5. Singhal A, Cole TJ, Fewtrell M, Deanfield J, Lucas A 2004 Is slower early growth beneficial for long-term cardiovascular health? Circulation 109:1108-1113

6. Singhal A, Fewtrell M, Cole TJ, Lucas A 2003 Low nutrient intake and early growth for later insulin resistance in adolescents born preterm. Lancet 361:1089-1097

7. Gluckman PD, Hanson MA 2004 Living with the past: evolution, development and patterns of disease. Science 305:1773-1776

8. Vickers MH, Breier BH, Cutfield WS, Hofman PL, Gluckman PD 2000 Fetal origins of hyperphagia, obesity, and hypertension and postnatal amplification by hypercaloric nutrition. Am J Physiol Endocrinol Metab 279:E83-E87

9. Vickers MH, Breier BH, McCarthy D, Gluckman PD 2003 Sedentary behavior during postnatal life is determined by the prenatal environment and exacerbated by postnatal hypercaloric nutrition. Am J Physiol Regul Integr Comp Physiol 285:R271-R273

10. Bellinger L, Lilley C, Langley-Evans SC 2004 Prenatal exposure to a maternal low-protein diet programmes a preference for high-fat foods in the young adult rat. Br J Nutr 92:513-520

11. Silveira PP, Portella AK, Clemente Z, Bassani E, Tabajara AS, Gamaro GD, Dantas G, Torres IL, Lucion AB, Dalmaz C 2004 Neonatal handling alters feeding behavior of adult rats. Physiol Behav 80:739-745

12. Silveira PP, da Silva Benetti C, Ayres C, Pederiva FQ, Portella AK, Lucion AB, Dalmaz C 2006 Satiety assessment in neonatally handled rats. Behav Brain Res 173:205-210

13. Barbieri MA, Bettiol H, Silva AA, Cardoso VC, Simões VM, Gutierrez MR, Castro JA, Vianna ES, Foss MC, Dos Santos JE, Queiroz RG 2006 Health in early adulthood: the contribution of the 1978/79 Ribeirao Preto birth cohort. Braz J Med Biol Res 39:1041-1055

14. Kramer MS, Platt R, Yang H, McNamara H, Usher RH 1999 Are all growthrestricted newborns created equal(ly)? Pediatrics 103:599-602

15. Matsudo V, Matsudo S, Andrade D, Araujo T, Andrade E, de Oliveira LC, Braggion G 2002 Promotion of physical activity in a developing country: the Agita São Paulo experience. Public Health Nutr 5:253-261

16. Shephard RJ, Lankenau B, Pratt M, Neiman A, Puska P, Benaziza H, Bauman A 2004 Physical activity policy development: a synopsis of the WHO/CDC Consultation, September 29 through October 2, 2002 Atlanta, Georgia. Public Health Rep 119:346-351

17. Goldani MZ, Barbieri MA, Silva AA, Bettiol H 2004 Trends in prenatal care use and low birthweight in southeast Brazil. Am J Public Health 94:1366-1371

18. Tomita LY, Cardoso MA 2002 Assessment of the food list and serving size of a food frequency questionnaire in an adult population. Cad Saude Publica 18:1747-1756

19. Keys A, Fidanza F, Karvonen MJ, Kimura N, Taylor HL 1972 Indices of relative weight and obesity. J Chronic Dis 25:329-343

20. Expert Panel on Detection, Evaluation, and Treatment of High Blood Cholesterol in Adults 2001 Executive summary of the third report of The National Cholesterol Education Program (NCEP) expert panel on detection, evaluation, and treatment of high blood cholesterol in adults (Adult Treatment Panel III). JAMA 285:2486-2497 
21. Olson CM, Bove CF, Miller EO 2007 Growing up poor: long-term implications for eating patterns and body weight. Appetite 49:198-207

22. Riediger ND, Shooshtari S, Moghadasian MH 2007 The influence of sociodemographic factors on patterns of fruit and vegetable consumption in Canadian adolescents. J Am Diet Assoc 107:1511-1518

23. Grove KL, Sekhon HS, Brogan RS, Keller JA, Smith MS, Spindel ER 2001 Chronic maternal nicotine exposure alters neuronal systems in the arcuate nucleus that regulate feeding behavior in the newborn rhesus macaque. J Clin Endocrinol Metab 86:5420-5426

24. Chen H, Vlahos R, Bozinovski S, Jones J, Anderson GP, Morris MJ 2005 Effect of short-term cigarette smoke exposure on body weight, appetite and brain neuropeptide Y in mice. Neuropsychopharmacology 30:713-719

25. Allen SS, Hatsukami D, Brintnell DM, Bade T 2005 Effect of nicotine replacement therapy on post-cessation weight gain and nutrient intake: a randomized controlled trial of postmenopausal female smokers. Addict Behav 30:1273-1280

26. Seckl JR, Meaney MJ 2006 Glucocorticoid "programming" and PTSD risk. Ann N Y Acad Sci 1071:351-378

27. Jones A, Godfrey KM, Wood P, Osmond C, Goulden P, Phillips DI 2006 Fetal growth and the adrenocortical response to psychological stress. J Clin Endocrinol Metab 91:1868-1871

28. Piazza PV, Le Moal M 1997 Glucocorticoids as a biological substrate of reward: physiological and pathophysiological implications. Brain Res Brain Res Rev 25:359-372

29. Dallman MF, Pecoraro N, Akana SF, La Fleur SE, Gomez F, Houshyar H, Bell ME, Bhatnagar S, Laugero KD, Manalo S 2003 Chronic stress and obesity: a new view of "comfort food." Proc Natl Acad Sci USA 100:11696-11701

30. Epel E, Lapidus R, McEwen B, Brownell K 2001 Stress may add bite to appetite in women: a laboratory study of stress-induced cortisol and eating behavior. Psychoneuroendocrinology 26:37-49

31. Ravelli AC, van Der Meulen JH, Osmond C, Barker DJ, Bleker OP 1999 Obesity at the age of $50 \mathrm{y}$ in men and women exposed to famine prenatally. Am J Clin Nutr 70:811-816

32. Montano MM, Wang MH, vom Saal FS 1993 Sex differences in plasma corticosterone in mouse fetuses are mediated by differential placental transport from the mother and eliminated by maternal adrenalectomy or stress. J Reprod Fertil 99:283290

33. Vickers MH, Gluckman PD, Coveny AH, Hofman PL, Cutfield WS, Gertler A, Breier BH, Harris M 2005 Neonatal leptin treatment reverses developmental programming. Endocrinology 146:4211-4216

34. Shigemura N, Ohta R, Kusakabe Y, Miura H, Hino A, Koyano K, Nakashima K, Ninomiya Y 2004 Leptin modulates behavioral responses to sweet substances by influencing peripheral taste structures. Endocrinology 145:839-847

35. Shultis WA, Leary SD, Ness AR, Bain CJ, Emmett PM; ALSPAC Study Team 2005 Does birth weight predict childhood diet in the Avon longitudinal study of parents and children? J Epidemiol Community Health 59:955-960

36. Klesges RC, Malott JM, Boschee PF, Weber JM 2006 The effects of parental influences on children's food intake, physical activity, and relative weight. Int J Eat Disord 5:335-345

37. Cerro N, Zeunert S, Simmer KN, Daniels LA 2002 Eating behaviour of children 1.5-3.5 years born preterm: parents' perceptions. J Paediatr Child Health 38:72-78

38. Silveira PP, Portella AK, Crema L, Correa M, Nieto FB, Diehl L, Lucion AB, Dalmaz C 2008 Both infantile stimulation and exposure to sweet food lead to an increased sweet food ingestion in adult life. Physiol Behav 93:877-882
39. Ford ES, Giles WH 2003 A comparison of the prevalence of the metabolic syndrome using two proposed definitions. Diabetes Care 26:575-581

40. Monteiro CA, Conde WL, Popkin BM 2007 Income-specific trends in obesity in Brazil: 1975-2003. Am J Public Health 97:1808-1812

41. Dumesnil JG, Turgeon J, Tremblay A, Poirier P, Gilbert M, Gagnon L, St-Pierre S, Garneau C, Lemieux I, Pascot A, Bergeron J, Després JP 2001 Effect of a low-glycaemic index-low-fat-high protein diet on the atherogenic metabolic risk profile of abdominally obese men. Br J Nutr 86:557-568

42. Du XL, Edelstein D, Rossetti L, Fantus IG, Goldberg H, Ziyadeh F, Wu J, Brownlee M 2000 Hyperglycemia-induced mitochondrial superoxide overproduction activates the hexosamine pathway and induces plasminogen activator inhibitor-1 expression by increasing Sp1 glycosylation. Proc Natl Acad Sci USA 97:12222-12226

43. Layman DK, Boileau RA, Erickson DJ, Painter JE, Shiue H, Sather C, Christou DD 2003 A reduced ratio of dietary carbohydrate to protein improves body composition and blood lipid profiles during weight loss in adult women. J Nutr 133:411-417

44. Layman DK, Shiue H, Sather C, Erickson DJ, Baum J 2003 Increased dietary protein modifies glucose and insulin homeostasis in adult women during weight loss. J Nutr 133:405-410

45. Oh K, Hu FB, Cho E, Rexrode KM, Stampfer MJ, Manson JE, Liu S, Willett WC 2005 Carbohydrate intake, glycemic index, glycemic load, and dietary fiber in relation to risk of stroke in women. Am J Epidemiol 161:161-169

46. Ross CE, Bird CE 1994 Sex stratification and health lifestyle: consequences for men's and women's perceived health. J Health Soc Behav 35:161-178

47. Kruger J, Yore MM, Ainsworth BE, Macera CA 2008 Physical activity patterns associated with weight-control status: differences by race and sex. J Phys Act Health 5:456-468

48. Reichard YK, Alricsson M, Werner S 2008 Self-related health, physical activity and musculoskeletal complaints in Swedish high school students. Minerva Pediatr 60:263-271

49. Schaefer EJ, Augustin JL, Schaefer MM, Rasmussen H, Ordovas JM, Dallal GE, Dwyer JT 2000 Lack of efficacy of a food-frequency questionnaire in assessing dietary macronutrient intakes in subjects consuming diets of known composition. Am J Clin Nutr 71:746-751

50. Larson NI, Neumark-Sztainer DR, Harnack LJ, Wall MM, Story MT, Eisenberg ME 2008 Fruit and vegetable intake correlates during the transition to young adulthood. Am J Prev Med 35:33-37

51. Promislow JH, Gladen BC, Sandler DP 2005 Maternal recall of breastfeeding duration by elderly women. Am J Epidemiol 161:289-296

52. Gillespie B, d'Arcy H, Schwartz K, Bobo JK, Foxman B 2006 Recall of age of weaning and other breastfeeding variables. Int Breastfeed $\mathrm{J}$ 1:4

53. Apfelbacher CJ, Loerbroks A, Cairns J, Behrendt H, Ring J, Krämer U 2008 Predictors of overweight and obesity in five to seven-year-old children in Germany: results from cross-sectional studies. BMC Public Health 8:171

54. Michels KB, Willett WC, Graubard BI, Vaidya RL, Cantwell MM, Sansbury LB, Forman MR 2007 A longitudinal study of infant feeding and obesity throughout life course. Int J Obes (Lond) 31:1078-1085

55. Basaldúa N, Chiquete E 2008 Common predictors of excessive adiposity in children from a region with high prevalence of overweight. Ann Nutr Metab 52:227-232

56. Forestell CA, Mennella JA 2007 Early determinants of fruit and vegetable acceptance. Pediatrics 120:1247-1254 